\title{
Students Perception and Willingness to E- learning in Republic of Croatia
}

\author{
Natalija Kokolek, Dajana Ćorić, Božidar Jaković \\ Faculty of Economics \& Business, University of Zagreb, Croatia
}

\section{Abstract}

The subject of this paper is e - learning, education process which is held with the use of some form of information and communication technologies to improve the quality of the process and the quality of educational outcomes. New information technologies allow a new attitude to information, digitalization, easy and quickly storing, reproduction, distribution and use. Internet provides us with a variety of opportunities for creativity and the spread of new ideas and knowledge, pushing the boundaries of what we consider our own environment. Through this paper the importance of e - learning as an integral part of the today's educational process will be shown. This paper will take us through the theme of e-learning starting from its definition, historical development of its types, then the technological aspects, statistical information on the topic and it will analyse the survey based on the research. Research on students perception in Republic of Croatia about e-learning will show that Republic of Croatia has a relatively favourable environment for the development and implementation on Croatian universities, and that application of new technologies on the Croatian universities achieves a significant impact on the efficiency of the teaching process.

Keywords: e-learning, education, ICT, Internet

JEL classification: 121, O31, A22, A23, 121

\section{Introduction}

Today's era of modern technology and globalization brings rapid change in all aspects of human life. There is a need for faster, timely education, which will also be open and widely available (Sloman; 2002, pp.11). The use of new technologies has enabled education becomes one of the fastest growing sectors in the world (McGreal, Elliott; 2004, pp.41)

E - learning is a cross-section of two worlds, the world of "information and communication technology" and the world of "education". It is precious, especially when used as part of a well-planned and organized environmental education, but certainly, e-learning is not a "magic ball" that will replace and put out of use existing pedagogical theory, principles and norms. The fundamental values of e-learning can be detected by using student achievement in the process of teaching and learning and appreciating the system of e-learning (Stankov; 2009, pp.5)

There are many definitions of e-learning which, depending on their nature, generally can be classified into one of two groups: technical and pedagogical. The first group is those that emphasize the technical component. According to them, e - learning is any form of education based on the use of modern technology, especially computers and computer networks. Information and communication technologies are considered at the same time a key factor in the educational process. Another group definition emphasizes the educational component. Consequently, e-learning is referred to as an interactive process between teachers 
and students that is technologically supported. In these definitions, information and communication technologies are treated as a resource to achieve the pedagogical and educational goals.

Since the degree of satisfaction, in this case, of the current and former students, is one of the indicators of quality of services in colleges, conducted survey aimed to identify the status of the universities in the opinion of students regarding the application of ICT in university teaching, and also consideration of the long-term vision and their expectations from the using of ICT in the educational process.

Users require high quality of the virtual world that is rich in possibilities. The success of e - learning depends on building customer relationships and institutions. It requires a network of qualified people who are committed to offering the highest possible quality of learning. Data should be collected regularly and diagnose the strengths and opportunities. There is no space for mediocrity (Barron; 2006, pp.360-364. ).

This paper takes us through the theme of e - learning, starting from its definition, technological aspects, statistical information on the topic and an analysis of the survey and recommendations based on the research. The aim was to examine the former and current students on the state of e-learning in Croatia and its application to universities and various forms of teaching.

\section{Literature review}

Topolovec et al. (2008) investigated different ways in which modern technology and the "knowledge age" change the work environment, which causes continuous effort and learning for almost all kinds of jobs and occupations. The paper shows paradigms of using ICT in the teaching and learning process, as well as main paradigm characteristics through different settings from different levels of abstraction. The paper also illustrates indicators of the result of ICT usage in learning and teaching processes, which represent a sort of strategies and enable measuring the influence of ICT to learning and teaching processes. New knowledge provided by cognitive, social, pedagogic, information and computer scientists and subject matter specialists studying learning and teaching has generated advances in our understanding of learning and teaching processes and contributes substantially to our understanding of how to use ICT to improve and transform learning and teaching.

Crnjac Milic et al. (2009) investigated the process of learning by using ICT as a platform the goal of which is to facilitate accessibility and flow of information as well as interaction among participants involved in learning, which aims at improving the learning process itself. According to the authors and their research on engineering faculties shows that both teachers and students are ready and more than willing to introduce such form of teaching and learning. It has been emphasized that there should be no fear that such forms of teaching and learning might push the teacher out of the teaching / learning process, since such systems represent only a platform through which the teacher teaches.

Penny et al. (2012) have made a study where they conducted a questionnaire survey to gather information on students' experiences and usage of ICT during their university studies. The questionnaire survey was carried out in two universities: Edinburgh Napier University in Scotland and the Josip Juraj Strossmayer University of Osijek in Croatia. The findings presented in this study has shown that male students were more likely to use specialised software for designing, drawing, mathematics or statistics than females, as were students in Croatia and students studying engineering, physics, computative and creative industries. Scottish students were more likely than Croatian students to use ICT for acquiring educational information, 
and females were more likely to participate in writing essays and preparing presentations. Also, it has been confirmed that students who participate in online activities are more likely to be higher achievers educationally.

Mishra et al. (2011) have discussed e - learning experiences from the faculty's perspective on different attributes and contexts in a comparative view at three premier universities which provide online courses for students and professionals. According to their experiences, teachers should be well trained and motivated to facilitate $e$ - learning which is more effective for experienced professionals and students in comparison to new students. Also, for graduate level courses, text books should always complement online course material content and pointers for additional readings.

According to Duh et al. (2011) the basic principal of education is still transfer of knowledge. E-learning materials are just one example of support material in the education process, but they can help promote self-learning at all levels of education. The basic principle of education is still transfer of knowledge.

\section{Methodology}

A questionnaire survey was designed to gather information on students' experiences and consideration of the long-term vision and their expectations from usage of ICT during their university studies and the educational process. The questionnaire survey was carried out during March to May 2013 on a population of 257 people, electronically and via Facebook. Survey participants completed anonymously and the data were statistically analysed in the software package Google Drive.

At the beginning of the questionnaire, participants were asked to provide some demographic information e.g. age, gender, and some details regarding their studies like type of degree.

The next section on the questionnaire asked students to provide details of how often, week and daily frequency, they are using a computer or the Internet for various tasks related to their studies and tasks.

The last group of questions was related to the participants opinions on the application of ICT in education, their presence on the various forms of teaching during their education, attending various courses and about technology in $e-$ learning in the future.

\section{Results}

From a total of 257 participants, $27 \%$ participants were male population, while the remaining $73 \%$ or 188 participants belonged to women population. Among those questioned, most of the population was between $18-24$ years, or $90 \%$, and $7 \%$ of those between 25 - 34 years and at the end $3 \%$ of participants older than 35 years.

Opinion on e - learning regarding qualifications gave 213 students, or $83 \%$, followed by $8 \%,(20)$ respondents who have secondary education, and at least $3 \%$ respondents (8) with a higher and 6\% (16) with high education.

According to data from the Centre for Market Research from 2012, the Internet users most often uses it at home $(87 \%)$, work (10\%) and other places (3\%). Of these users, $16 \%$ of them are considered to be addicted to the Internet, and the remaining $84 \%$ of participants disagreed with this statement.

According to the results from the survey the largest number of users, 136 of them (53\%) used the Internet from one to three hours a day. 76 (30\%) participants spent four to five hours a day on the Internet, and 32 (12\%) participants used the Internet 
for six hours or more. A small number of participants, 13 (5\%), spent less than an hour a day on the Internet.

In Croatia, $68 \%$ of households have a personal computer according to the survey, of Croatian bureau of statistics, on the use of information and communication technologies in households in 2012. Compared to the previous year, it was noticed a slight increase of $4 \%$ of household equipment of ICT. In 2012, the computer and the Internet usage was at a satisfactory level only within younger population up to age of $24,96 \%$ of them use a computer, of which $92 \%$ aged from 25 to 34 . There is an increase in all age groups except the elderly population. Only $12 \%$ of people older than 65 used a computer and the Internet, and 32\% of those are from 55 to 64 years old.

Of the 257 survey participants, 191 of them or $74 \%$ have their own personal computer in their household, and the other 66 , i.e. $26 \%$ of them do not have it in their household.

Internet is now used for different purposes, from providing information about daily events, sending and receiving e-mails, using social networks, seeking for information about products and services, online shopping and Internet banking service provider, to Internet streaming radio, television viewing, downloading music, gaming, downloading games. According to the survey, $99 \%$ of respondents used some of the services Internet use every day, which included 187 women and 67 men. Only $1 \%$ of respondents used the Internet every second day.

Technology development, no matter what the scope of it is, undoubtedly contributes to the development of human society. Although we are aware of all the benefits and new opportunities that would contribute to the e-learning in education, the reality is somewhat different. $35 \%$ of respondents, or 90 of them believe that the conditions are negative (18 men and 72 women), and $29 \%$ (74) of participants (19 men and 55 women) believe that the application of e-learning is favourable. $30 \%$ of respondents were neutral in terms of applications, and $6 \%$ or 15 participants (8 men and 7 women) think that the situation is extremely favourable for the implementation of e - learning in the educational system.

$24 \%$ of participants have a positive attitude on the relationship between teachers and their application of ICT in education, and 5\% of them believe that teachers easily accept all ICT news. 34\% of respondents were neutral, while $30 \%$ of them thought that ICT is rarely used in teaching. 19 of respondents or $7 \%$ of them expressed a negative attitude, and said that teachers do not use ICT during lectures. The largest number of respondents, 152 or $59 \%$ of them have a positive attitude on the application of ICT in education, and a very positive attitude presented $20 \%$ of participants. The negative attitude had 5 participants or $2 \%$ of them. $19 \%$ of them of participants were either restrained or had neutral opinion.

The next question to which respondents answered in the survey was related to their presence on the various forms of teaching during their education, attending various courses, language schools and etc.

The largest number of respondents, 236 attended the classic form of education, followed by 196 students who attended hybrid or mixed education classes, and at least 141 respondents attended to classes using the ICT. Online education was used by only $17 \%$ of the respondents, or 44 of them. 
Table 1

The presence of participants in various forms of education by education level

\begin{tabular}{|c|c|c|c|c|c|c|c|c|}
\hline & \multicolumn{2}{|c|}{$\begin{array}{l}\text { Classical } \\
\text { Education }\end{array}$} & \multicolumn{2}{|c|}{$\begin{array}{l}\text { Education } \\
\text { using the ICT }\end{array}$} & \multicolumn{2}{|c|}{$\begin{array}{l}\text { Hybrid or } \\
\text { mixed } \\
\text { Education }\end{array}$} & \multicolumn{2}{|c|}{$\begin{array}{l}\text { Online } \\
\text { Education }\end{array}$} \\
\hline & Yes & No & Yes & No & Yes & No & Yes & No \\
\hline Student & 197 & 16 & 115 & 98 & 160 & 56 & 37 & 176 \\
\hline $\begin{array}{l}\text { Secondary } \\
\text { education }\end{array}$ & 17 & 3 & 16 & 4 & 18 & 2 & 5 & 15 \\
\hline $\begin{array}{c}\text { Higher } \\
\text { education }\end{array}$ & 8 & 0 & 5 & 3 & 6 & 2 & 0 & 8 \\
\hline $\begin{array}{c}\text { High } \\
\text { education }\end{array}$ & 14 & 2 & 5 & 11 & 12 & 1 & 2 & 14 \\
\hline
\end{tabular}

Source: Authors' table

Those respondents who accessed some form of online of teaching, in the survey stated forms with which they are familiar. Among the responses were the following:

- College of International Economics in Moodle, E - course International Entrepreneurship at the Merlin system, a seminar held on the Google Hangout Conference Global Mergers and Acquisitions, Baltazar video lectures and materials, online learning Alphabet Management, online classes Music, Marketing e - learning, online courses through Coursera websites, presentations, videos and materials available on the Webinars website.

From $47 \%$ of participants who joined the e - learning, 85 of them (64\%) used the Moodle during their education. Merlin system was used by $27 \%$ of participants (36) and the MoD system by $2 \%$ of them.

The last question in the survey required from respondents to give their opinion on will in the future come to serious process of implementing of e - learning in higher education in Croatia. 53\% of participants, of which 112 students, 11 with secondary education, 4 with a college degree and 8 with higher education believe that there will be a development of e-learning in the educational system, while the remaining $47 \%$ of participants stated denial.

Summarizing the results of the survey, it can be concluded that there is a relatively favourable environment for the development and implementation of e - learning in higher education in the Croatia and that the application of new technologies to the Croatian universities would achieve a significant impact on the efficiency of the teaching process.

\section{Discussion}

Education is one of the most important factors responsible for the development of society, and its adaptation to changes brought by today's information age is very important. It is considered to in order to successfully achieve this adjustment it is not enough to change and modernize only learning content. It is equally important to make changes on teaching methods. Today, more and more is emphasized the need for education based on the methods used by information and communication technology.

The survey results do not surprise with the fact that $99 \%$ of participants each day use some of Internet use services. It is considered that the results of survey show that users have recognized the advantages offered by a global network that has no 
barriers and boundaries, and is available in every part of the planet Earth, of course, with the right equipment.

What do surprise are results related to the situation in universities related to implementation of $e$ - learning in education. A number of respondents had a negative view and $35 \%$ of them believe that the situation is unfavourable. Considering that in the process of implementing $e$ - education is a comprehensive systemic change, it needs to be implemented from top to bottom. A great number of competences are needed, from education managers, instructional designers, technical support, to the teachers who know how to apply the technology. As the results of the survey confirmed, about $29 \%$ of respondents believe that teachers have a very positive or positive attitude on the application of ICT in education, and $71 \%$ of respondents believe that teachers occasionally, rarely or not at all apply ICT in teaching. Inadequate implementation of e - education with unprofessional and poor quality educational use of technology can make us more harm than good. Ministry of Science, Education and Sports should enable training for teachers and training for management, skill trainings and so on. Although the government is making efforts to increase investment in education, it is still far below the EU average due to lack of funds.

As a limitation of this study considered could be number of participants and their distribution according to age and education level.

In the future research more participants could be included, and better distribution could be done so that survey have an equal number of participants at each level of education what should give more reliable and more significant results. Also, this survey could be sent to the Universities administration of each Faculty in the Republic of Croatia, so that results could be more significant and official at the state level. Furthermore, results obtained in the Republic of Croatia could be compared to some other countries, so that comparison could be shown and could give guidelines how to fix possible issues when applying IT in education.

Regarding the respondents' opinions about the serious process of implementing e learning in higher education in Croatia, 53\% of them believe that there will be a development of e - learning in education as expected.

\section{Conclusion}

Today, e - learning is most often associated with the Internet which continuously development allows faster and better communication among all people. We live in an age of universal information - communication revolution which is characterized by increasing internationalization, globalization and integration. Today is almost impossible to imagine formal and informal education without the use of computers and new technologies. Computers and Internet have become common place for students, before, after, or during the teaching process and the data show that in the world there are even 2.4 billion Internet users, of which 1.1 billion are coming from Asia, and 519 million people access the Internet from Europe. Thanks to the large increase in application of education, today's pupils and students have selectable fast and functional learning.

$\mathrm{E}$ - learning with new technologies is one of the biggest challenges in recent years facing higher education in the Republic of Croatia. It's implementation significantly improves the quality and increases the competitiveness of our education system. This directly contributes to the improvement of the educational structure as a necessary precondition for the progress of society. According to the conducted survey it can be seen point to a relatively favourable environment for the development and implementation of $e$ - learning in higher education in Croatia, and that the 
application of new technologies to the Croatian universities achieves a significant impact on the efficiency of the teaching process.

Although we are aware of all the benefits and new opportunities that would contribute to e-learning in education, the reality is somewhat different. $35 \%$ of respondents, or 90 of them believe that the conditions are negative (18 men and 72 women), and $29 \%$ (74) of participants (19 men and 55 women) believe that the application of e - learning is favourable. $53 \%$ of respondents, of which 112 students, 11 with secondary education, 4 with a college degree and 8 with higher education, believe that there will be a development of e-learning in the educational system, while the remaining $47 \%$ of respondents stated denial.

In the future research more participants could be included, and better distribution could be done so that survey have an equal number of participants at each level of education what should give more reliable and more significant results.

Authors of this paper believe that technology in the teaching process is just a tool to achieve outstanding educational outcomes just as unprofessional and poorly use of educational technology can create significantly more problems than benefits.

\section{References}

1. Barron, J. (2006), "Top ten secrets of effective e - learning", Industrial and commercial training Journal, Emerald, http://www.emeraldinsight.com/journals.htm?issn=00197858 \& volume $=38$ \&issue $=7$ \&articleid $=1576431$ \&show $=h t m l \&$ (accessed June $20^{\text {th }} 2015$ )

2. Crnjac Milic, D., Martinovic, G., Fercec, I. (2009), "E -learning: Situation and perspectives", Tehnički vjesnik, Vol. 16 No. 2, pp. 31-36.

3. Duh, M., Krasna, M. (2011), "Distance learning - Communication quality", Informatologia, Vol. 44 No. 2, pp. 131-136.

4. McGreal, R., Elliott, M (2004), "Tehnologies of Online Learning (e-Learning)", Athabasca University, Athabasca.

5. Mishra, A., Mishra, D. (2011), "E-learning experience at various universities: Academics perspective", Tehnički vjesnik, Vol. 18 No. 1, pp. 133-140.

6. Penny, K., Dukic, D. (2012), "E-learning Participation in Higher Education: A study of Scottish and Croatian Students", CIT. Journal of Computing and Information Technology, Vol. 20 No. 3, pp. 183-188.

7. Sloman, M. (2002), "The e - learning revolution", CIPD, London.

8. Stankov, S. (2009), "E - Učenje" ["E - learning"], Split.

9. Topolovec, V., Marinovic, M., Pavlic, M. (2008), "Information and communications technologies and the transformation of learning and teaching process for the $21^{\text {st }}$ century", Informatologia, Vol. 41 No. 4, pp. 293-303.

\section{About the authors}

Natalija Kokolek is with the University of Zagreb, 10000 Zagreb Croatia. She is a student on postgraduate (doctoral) study programme. Author can be contacted at nkokolek@gmail.com.

Dajan Ćorić is with the University of Zagreb, 10000 Zagreb Croatia. She is a student on postgraduate (doctoral) study programme. Author can be contacted at dajana.coric@gmail.com.

Božidar Jaković is with the University of Zagreb, 10000 Zagreb Croatia. He is now with the Department of Informatics, Faculty of Economics and Business. Author can be contacted at bjakovic@efzg.hr 